\title{
Late Oral Complications Caused by Head and Neck Radiotherapy: Clinical and Laboratory Study
}

\author{
Adriane C. Martinez ${ }^{1}$, Isabela M. V. Silva ${ }^{2}$, Soraya. A. Berti Couto ${ }^{2}$, Rinaldo F. Gandra ${ }^{3}$, \\ Edvaldo A. R. Rosa', Aline C. B. R. Johann², Paulo H. Couto Souza ${ }^{2}$ \\ ${ }^{1}$ School of Biological Sciences and Healthcare, Department of Dentristry, Western Paraná State University, Cascavel, Brazil. \\ ${ }^{2}$ School of Life Sciences, Department of Dentristry, Pontifícia Universidade Católica do Paraná, Curitiba, Brazil. \\ ${ }^{3}$ School of Pharmaceutical Sciences and Medicine, Department of Pharmaceutical Sciences, Western Paraná State University, \\ Cascavel, Brazil.
}

\author{
Corresponding Author: \\ Paulo Henrique Couto Souza \\ School of Life Sciences, Department of Dentistry \\ Pontifícia Universidade Católica do Paraná \\ Rua Imaculada Conceição 1155 - 80215-901, 80215-901, Curitiba, Paraná \\ Phone: +55 4199945 9885/3271 2161 \\ E-mail: couto.s@pucpr.br
}

\begin{abstract}
Objectives: The aim of presented cross-sectional and observational study was to determine the prevalence of late oral complications of patients with head and neck cancer who underwent radiotherapy, by clinical and laboratory analyses.

Material and Methods: Fifty-five patients, 43 (78.2\%) men and 12 (21.8\%) women, mean age 60; range 38 to 87 years, who have completed radiotherapy for head and neck cancer for at least 6 months were enrolled. The presence of xerostomia, hyposalivation, oral candidiasis, and type of oral yeasts were correlated with post-radiotherapy period. A control group, age and gender matched, was used for comparisons. The Pearson's Chi-square or Fischer's exact test was used at a significance level of $5 \%$.

Results: The mean post-radiotherapy period was 32 months. The oral complications found were xerostomia (45/55, [81.8\%]), hyposalivation (44/55 [80\%]) and oral candidiasis (15/55 [27.2\%]). Xerostomia and hyposalivation was statistically higher in the study group when compared to the control group $(\mathrm{P}<0.05)$. The presence of yeast occurred in $39(70.9 \%)$ of the patients in the study group, and Candida albicans was the most prevalent etiological agent in $25(64.1 \%)$ of those patients $(\mathrm{P}<0.05)$. Conclusions: Xerostomia and hyposalivation were the more prevalent late oral complications related to radiotherapy. Oral candidiasis was also observed, although its prevalence was lower. The need for long-term dental follow-up of patients who underwent radiotherapy of the head and neck cancer is mandatory.
\end{abstract}

Keywords: candida albicans; postoperative complications; radiotherapy; xerostomia.

Accepted for publication: 29 September 2020

To cite this article:

Martinez AC, Silva IMV, Berti Couto SA, Gandra RF, Rosa EAR, Johann ACBR, Couto Souza PH.

Late Oral Complications Caused by Head and Neck Radiotherapy: Clinical and Laboratory Study

J Oral Maxillofac Res 2020;11(3):e3

URL: http://www.ejomr.org/JOMR/archives/2020/3/e3/v11n3e3.pdf

doi: $10.5037 /$ jomr.2020.11303 


\section{INTRODUCTION}

According to the information from Globocan/Iarc, in $2018,354,864$ new cases of lip and oral cavity cancers have been estimated worldwide [1]. In Brazil, 11,200 new cases of oral cavity cancer in men and 3,500 in women were estimated for each year in 2018 to 2019 biennium [2]. Radiotherapy has been the basic treatment for the majority of head and neck cancers and it can be used alone or combined with chemotherapy and/or surgery, depending on the characteristics of the tumour and therapeutic planning $[\underline{3}, \underline{4}]$. The main action of radiation is to prevent the duplication of deoxyribonucleic acid (DNA) molecules, either directly via DNA cleavage or indirectly by the reaction of hydroxyl (OH-) groups, derived from the dissociation of water molecules, with DNA bases [ [ $\underline{5}$.

The cellular changes produced by radiation are also dose-dependent in healthy cells, and doses higher than 45 Gy used bilaterally in the mouth, joints, and salivary glands caused adverse effects, which reduce the patient's quality of life during and specifically after the treatment $[\underline{6}, \underline{7}]$.

Late or chronic oral complications are considered those that persist for more than 90 days after the end of radiotherapy, and their severity is primarily related to the radiation dose, treatment area, and patient's oral conditions []]. There are still few studies that have investigated late oral complications of radiotherapy of head and neck cancer by means of clinical and laboratory evaluation when analysed in combination.

This study aimed to determine the prevalence of late oral complications in patients who underwent radiotherapy for head and neck cancer using clinical and laboratory analyses.

\section{MATERIAL AND METHODS}

This cross-sectional and observational study was approved by the Ethics Committees for Research of Western Paraná State University, under the protocol No. 597/2010. The study was conducted between January 2011 to December 2014 and informed consent was obtained from all participants included in the sample.

This study included two groups of patients. The study group consisted of consecutive patients who underwent radiotherapy in the head and neck regions at the Hospital of Western Paraná Union of Studies and Fight against Cancer (UOPECCAN), older than 18 years and presenting with physical and psychological conditions to attend clinical consultations. Patients who received radiation therapy only in the cervical region or those treated with radiotherapy for skin and lip cancers were not included in the study. All patients were treated with the $6 \mathrm{MV}$ Linear Photon Accelerator (model CLINAC 600C; Varian Medical Systems; Palo Alto, USA) using the two-dimensional conventional radiotherapy technique (Figure 1). The control group included consecutive patients from the Dental Clinic of the State University of Western Paraná (UNIOESTE Dental Clinic), who did not undergo radiotherapy in the head and neck regions, and whose age and gender were matched to those of the study group.

Clinical evaluation was conducted by a single experienced dentist specialized in stomatology while laboratory analyses were conducted by a single experienced pharmacist specialized in microbiology who was blinded to the patients' information. The study first stage was conducted at the UOPECCAN Hospital and involved the collection of therapeutic data from the medical records of patients from the study group. In the second stage, clinical and laboratorial examination of the study and control patients were conducted at the UNIOESTE Dental Clinic.

\section{Xerostomia}

Xerostomia was evaluated using the criteria established by Berti-Couto et al. [9]. The complaints related to xerostomia were dry mouth, difficulty in chewing and swallowing dry food, and an increase in the frequency of fluid/water intake. The degree of dryness of the jugal mucosa was then assessed by visual inspection and palpation, and the degree of adhesion in the mucosal surface was performed using a wooden spatula. The amount of saliva accumulated on the floor of the mouth and the functional test of the major salivary glands were evaluated by inspection and extraoral palpation of these glands, as complementary tests. Thus, the outcome of the xerostomia complaint was scored as 0 , meaning absence of the symptom, and 1, meaning presence of the symptom [9].

\section{Hyposalivation}

Hyposalivation was identified by sialometry technique using non-stimulated saliva, which was collected from 9 a.m. to 11 a.m., and water and food were not consumed within $2 \mathrm{~h}$ before and after this period [1013]. The produced saliva was collected in a previously weighed sterile vial and placed in a thermal box. 


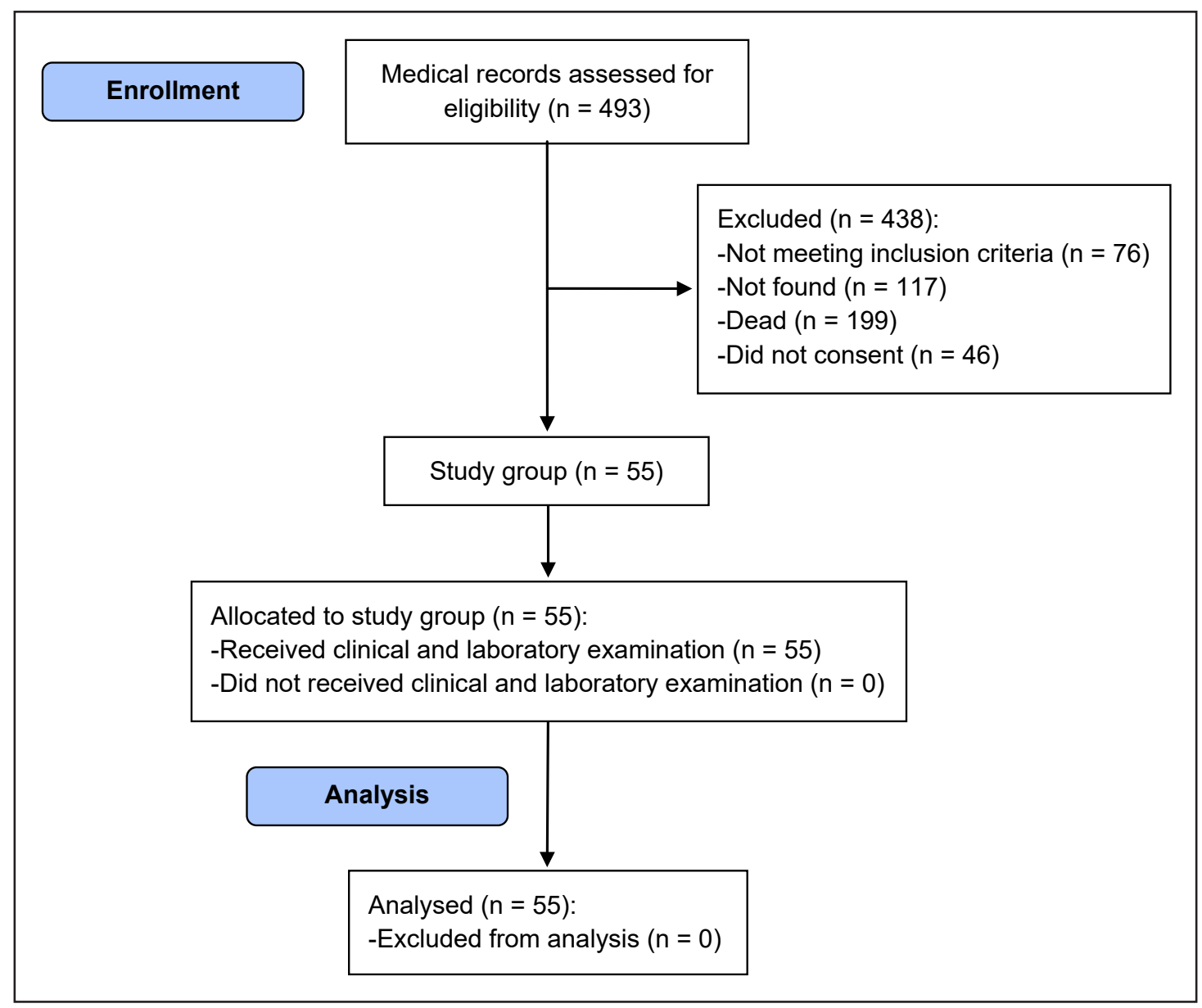

Figure 1. The Flow diagram to demonstrate the study group allocation.

The samples were weighed individually and converted into $\mathrm{mL} / \mathrm{min}$. The weight of each sample was measured on a precision scale and adjusted to flow in milligrams ( $\mathrm{mg} / \mathrm{min}$ ) assuming $1 \mathrm{mg}$ is equivalent to $1 \mathrm{~mL}$ [11]. Non-stimulated total salivary flow was considered a reference for the diagnosis of hyposalivation, when lower than $0.1 \mathrm{~mL} / \mathrm{min}$ [14] .

\section{Oral candidiasis}

Oral candidiasis was diagnosed based on the recognition of the clinical characteristics of each form, according to the following pre-established diagnostic criteria [15-17]: pseudomembranous, when the presence of detachable white plaques were identified; erythematous, acute, or chronic (associated with the use of complete upper denture), when asymptomatic reddish macules or pain and/or burning symptoms were observed; and angular cheilitis, when reddish, fissured, and bleeding lesions were identified in the labial commissure, uni- or bilaterally.

\section{Microbiological analysis}

The presence of yeasts in the saliva was identified after collecting samples in a sterile flask by oral rinsing, carried out with $10 \mathrm{~mL}$ of sterile water for $30 \mathrm{~s}$. The oral rinse samples were transferred to Petri dishes containing MycoselTM agar (Becton, Dickinson $[\mathrm{BD}]$ and Co.; São Paulo, Brazil) using a $10 \mu \mathrm{L}$ calibrated loop. The seeded plates were incubated at $37{ }^{\circ} \mathrm{C}$, and the number of colonies was counted after $48 \mathrm{~h}$ and expressed as colony-forming units per $\mathrm{mL}$ of oral rinse $(\mathrm{CFU} / \mathrm{mL})$. Patients with 1 to $399 \mathrm{CFU} / \mathrm{mL}$ were considered colonized, and those with counts of $\geq 400 \mathrm{CFU} / \mathrm{mL}$ were considered infected $[12, \underline{18-21]}$. The isolated yeasts were phenotypically identified with an auxanogram, the evaluation of germ-tube formation, and the production of chlamydoconidia according to the techniques described by Cooper [22] in 2011. The auxanogram was performed by transferring the yeasts obtained from clinical samples to Sabouraud agar Oxoid $^{\mathbb{R}}$ - Oxoid Limited; Basingstoke, United Kingdom) and culturing them for $24 \mathrm{~h}$ at $37^{\circ} \mathrm{C}$. Each sample was suspended in $2 \mathrm{~mL}$ of sterile saline solution. This suspension was transferred to a sterile Petri dish, and molten yeast nitrogen base (Difco ${ }^{\circledR}$ - Difco Laboratories Inc; Franklin Lakes, USA) was poured on the Petri dish and cooled to approximately $50{ }^{\circ} \mathrm{C}$. 
The culture was homogenized using the pour plate technique. After agar solidification, carbohydrates, dextrose, sucrose, galactose, xylose, trehalose, lactose, inositol, raffinose, dulcitol, and maltose were placed on an agar surface, and the plates were incubated in a bacteriological oven at 35 to $37^{\circ} \mathrm{C}$ for 18 to $24 \mathrm{~h}$. A positive test revealed the formation of an opaque halo around the metabolized sugar. The germ tube test was conducted by subculturing a yeast suspension containing $0.5 \mathrm{~mL}$ of fetal bovine serum on Sabouraud $2 \%$ agar $\left(\mathrm{Oxoid}^{\circledR}\right)$. This was incubated at 35 to $37^{\circ} \mathrm{C}$, and spectrophotometric values were read every 2 to $6 \mathrm{~h}$. After this period, a slide of the suspension was prepared, and the presence of germ tube was confirmed under an optical microscope using an $\mathrm{x} 40$ objective. The production of chlamydoconidia was assessed by the microculture technique using a slide and cornmeal agar as culture medium. The yeasts obtained from the subculture on Sabouraud agar $\left(\right.$ Oxoid $\left.^{\circledR}\right)$ was grown on cornmeal agar (Becton, Dickinson [BD] and Co.; São Paulo, Brazil) poured on the slide. A coverslip was placed on the agar surface to cover the streaks and the slid was incubated in a humid chamber at room temperature for 24 to $48 \mathrm{~h}$. After this period, the formation of chlamydoconidia was visualized under a microscope with an $\mathrm{x} 40$ objective.

\section{Statistical analysis}

The collected data were evaluated using Pearson's Chi-square and Fischer's exact tests, through the SPSS Statistics software, version 24.0 (IBM; New York, USA). Statistical significance level was defined at $\mathrm{P}=0.05$. Parametric data were expressed as mean values of frequency and their respective percentages.

\section{RESULTS}

A total of 55 patients in the study group and 55 patients in the control group (matched for age and gender) was enrolled. From the total sample 86/110 $(78.2 \%)$ were men and $24 / 110(21,8 \%)$ were women (mean age 60; range 38 to 87 ) and 40/110 (36.4\%) aged between 50 and 59 years in both groups. With regard to the patients' profile, $51 / 55(92.7 \%)$ of the study group were smokers and $86 / 110(78.1 \%)$ of the patients from both groups (34 in each group) used complete dentures. Xerostomic medication were used by $19(34.5 \%)$ of patients in the study group and 23 $(41.8 \%)$ of the control group, with antihypertensive and antidepressant medication as the most commonly used (Table 1).
Table 1. Demographic and clinical information of the participants

\begin{tabular}{l|c|c|c|c}
\hline \multirow{4}{*}{ Characteristics } & \multicolumn{2}{|c|}{$\begin{array}{c}\text { Study group } \\
(\mathrm{n}=\mathbf{5 5})\end{array}$} & \multicolumn{2}{c}{$\begin{array}{c}\text { Control group } \\
(\mathrm{n}=\mathbf{5 5})\end{array}$} \\
\cline { 2 - 4 } & Frequency & $(\%)$ & Frequency & $(\%)$ \\
\hline
\end{tabular}

Gender

\begin{tabular}{l|c|c|c|c}
\hline Female & 12 & 21.8 & 12 & 21.8 \\
\hline Male & 43 & 78.2 & 43 & 78.2 \\
\hline Age & 11 & 20 & 10 & 18.2 \\
\hline $38-49$ years & 20 & 36.4 & 20 & 36.4 \\
\hline $50-59$ years & 11 & 20 & 13 & 23.6 \\
\hline $60-69$ years & 13 & 23.6 & 12 & 21.8 \\
\hline$\geq 70$ years & &
\end{tabular}

Smoking

\begin{tabular}{l|c|c|c|c}
\hline Never & 4 & 7.3 & 21 & 38.2 \\
\hline Current smoker & 7 & 12.7 & 12 & 21.8 \\
\hline Ex-smoker & 44 & 80 & 22 & 40
\end{tabular}

Use of removable denture

\begin{tabular}{|c|c|c|c|c|}
\hline No & 12 & 21.8 & 12 & 21.8 \\
\hline One complete denture & 18 & 32.7 & 16 & 29.1 \\
\hline Two complete dentures & 19 & 34.5 & 21 & 38.2 \\
\hline Partial dentures & 6 & 10.9 & 6 & 10.9 \\
\hline \multicolumn{5}{|l|}{ Xerostomic medication } \\
\hline $\begin{array}{l}\text { One or more drugs } \\
\text { (antihypertensive/ } \\
\text { antidepressant) }\end{array}$ & 19 & 34.5 & 23 & 41.8 \\
\hline
\end{tabular}

Data analysis on diseases affecting patients in the study group indicated that the oropharynx and larynx were the most affected regions, representing $17(30.9 \%)$ and $16(29.1 \%)$ of the diagnoses, respectively. Clinical stage IV was the most common, corresponding to $20(36.4 \%)$ of the diagnoses. The post-treatment period ranged from 8 to 72 months (mean 32 months), with $19(34.5 \%)$ of the patients ranging from 19 to 36 months post-treatment. The radiation dose ranged from 22 to 70.2 Gy (Table 2).

Xerostomia was identified in $45(81.8 \%)$ of patients in the study group and $10(18.2 \%)$ of patients in the control group, with significant differences $(\mathrm{P}=0.0001)$ between the groups. Hyposalivation occurred in $44(80 \%)$ of patients in the study group and $12(21.8 \%)$ of patients in the control group, with a significant correlation $(\mathrm{P}=0.0001)$ between the groups (Table 3 ).

The most prevalent clinical form of candidiasis was chronic erythematous candidiasis, representing $8 / 15$ $(53.4 \%)$ of cases in the study group and 10/10 (100\%) of cases in the control group. Pseudomembranous and angular cheilitis forms were only identified in the study group, and 2/15 (13\%) of patients presented both forms simultaneously (Table 4). 
Table 2. Distribution of the number of head and neck tumours in patients who underwent radiotherapy at the Hospital of UOPECCAN $(\mathrm{n}=55)$

\begin{tabular}{|c|c|c|}
\hline Characteristics & Frequency & $\%$ \\
\hline \multicolumn{3}{|l|}{ Primary tumour site } \\
\hline Mouth & 14 & 25.5 \\
\hline Oropharynx & 17 & 30.9 \\
\hline Larynx & 16 & 29.1 \\
\hline Hypopharynx & 2 & 3.6 \\
\hline Salivary glands & 5 & 9.1 \\
\hline Unknown & 1 & 1.8 \\
\hline \multicolumn{3}{|l|}{ Tumour size $\left(\mathrm{TNM}^{\mathrm{a}}\right)$} \\
\hline $\mathrm{T} 1$ & 8 & 14.5 \\
\hline $\mathrm{T} 2$ & 10 & 18.2 \\
\hline $\mathrm{T} 3$ & 10 & 18.2 \\
\hline $\mathrm{T} 4$ & 17 & 30.9 \\
\hline $\mathrm{T} 4 \mathrm{a}$ & 5 & 9.1 \\
\hline Not informed & 5 & 9.1 \\
\hline \multicolumn{3}{|c|}{ Lymph node involvement (TNM $\left.{ }^{a}\right)$} \\
\hline N0 & 25 & 45.5 \\
\hline N1 & 14 & 25.5 \\
\hline $\mathrm{N} 2 \mathrm{a}$ & 10 & 18.2 \\
\hline $\mathrm{N} 2 \mathrm{~b}$ & 2 & 3.6 \\
\hline N3 & 3 & 5.5 \\
\hline Not informed & 1 & 1.8 \\
\hline \multicolumn{3}{|l|}{ Clinical stage } \\
\hline $\mathrm{I}$ & 3 & 5.5 \\
\hline II & 8 & 14.5 \\
\hline III & 17 & 30.9 \\
\hline IV & 20 & 36.4 \\
\hline IVa & 7 & 12.7 \\
\hline \multicolumn{3}{|l|}{ Histopathological diagnosis } \\
\hline Squamous cell carcinoma & 47 & 85.5 \\
\hline Others & 8 & 14.5 \\
\hline
\end{tabular}

\begin{tabular}{l|c|c}
\hline Oncological treatment & 5 & 9.1 \\
\hline Radiotherapy & 18 & 32.7 \\
\hline Radiotherapy and surgery & 18 & 32.7 \\
\hline Radiotherapy and chemotherapy & 14 & 25.5 \\
\hline Radiotherapy, surgery, and chemotherapy & \multicolumn{2}{l}{} \\
\hline Post-treatment period (months) & 16 & 29.1 \\
\hline $8-18$ & 19 & 34.5 \\
\hline $19-36$ & 11 & 20 \\
\hline $37-54$ & 9 & 16.4 \\
\hline $55-72$ & \multicolumn{2}{|}{} \\
\hline Dose (Gy) & 4 & 7.3 \\
\hline$\geq 22<50.5$ & 20 & 36.4 \\
\hline$\geq 50.5<64$ & 31 & 56.4 \\
\hline$\geq 64 \leq 70.2$ & \multicolumn{2}{|l}{}
\end{tabular}

${ }^{a}$ TNM, as proposed by the International Union against Cancer (UICC). Source: https://www.uicc.org/resources/tnm

$\mathrm{T} 4 \mathrm{a}=$ Tumours in advanced stages invading adjacent anatomical structures, depending on the tumour origin.

$\mathrm{N} 2 \mathrm{a}=$ Single regional lymph node involved, ipsilateral to the tumour.

$\mathrm{N} 2 \mathrm{~b}=$ Multiple regional lymph nodes involved, ipsilateral to the tumour.

$\mathrm{IVa}=\mathrm{T} 4 \mathrm{a}, \mathrm{N} 0$ or $\mathrm{N} 1, \mathrm{M} 0$ or, $\mathrm{T} 1$ to $\mathrm{T} 4 \mathrm{a}, \mathrm{N} 2, \mathrm{M} 0$.
Table 3. Distribution of the xerostomia and hyposalivation in patients who underwent radiotherapy at the Hospital of UOPECCAN $(\mathrm{n}=55)$

\begin{tabular}{l|c|c|c}
\hline \multirow{2}{*}{ Characteristics } & Study group & Control group & \multirow{2}{*}{ P-value $^{\mathbf{a}}$} \\
\cline { 2 - 3 } & $\mathbf{N}(\%)$ & $\mathbf{N}(\%)$ & \\
\hline Xerostomia & $45(81.8)$ & $10(18.2)$ & 0.0001 \\
\hline Hyposalivation & $44(80)$ & $12(21.8)$ & 0.0001 \\
\hline
\end{tabular}

aStatistically significant at the level $\mathrm{P}<0.05$ (Pearson's Chi-Square and Fischer's Exact test).

Table 4. Prevalence of clinical form of oral candidiasis in patients who underwent radiotherapy at the Hospital of UOPECCAN $(\mathrm{n}=55)$

\begin{tabular}{l|c|c|c}
\hline \multirow{2}{*}{ Types of candidiasis } & $\begin{array}{c}\text { Study } \\
\text { group }\end{array}$ & $\begin{array}{c}\text { Control } \\
\text { group }\end{array}$ & \multirow{2}{*}{ P-value } \\
\cline { 2 - 3 } & $\mathbf{N}(\%)$ & $\mathbf{N}(\%)$ & \\
\hline Chronic erythematous candidiasis & $8(53.3)$ & $10(100)$ & \\
\hline Pseudomembranous candidiasis & $3(20)$ & 0 & \multirow{2}{*}{$0.182^{\mathrm{b}}$} \\
\hline Angular cheilitis & $2(13.3)$ & 0 & \\
\hline $\begin{array}{l}\text { Pseudomembranous candidiasis } \\
\text { and angular cheilitis }\end{array}$ & $2(13.3)$ & 0 & \\
\hline Total & $15^{\mathrm{a}}(27.3)$ & $10^{\mathrm{a}}(18.2)$ & \\
\hline
\end{tabular}

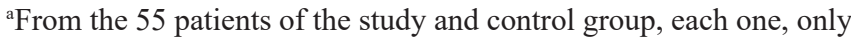
15 and 10 presented with oral candidiasis, respectively.

${ }^{b}$ Not statistically significant at the level $\mathrm{P}>0.05$ (Pearson's Chi-Square test)

The presence of yeast occurred in $39(70.9 \%)$ of patients in the study group and $6(10.9 \%)$ of patients in the control group. With regard to the number of colonies observed in colonized patients, 33/39 $(84.61 \%)$ in the study group and $4 / 6(66.7 \%)$ in the control group had a yeast count of $>400 \mathrm{CFU} /$ $\mathrm{mL}$. The yeast species identified in the study group were Candida albicans (25/39; 64.1\%), Candida tropicalis (5/39 [12.8\%]), Candida guilliermondii (4/39 [10.3\%]), Candida krusei (2/39 [5.1\%]), Candida glabrata (1/39 [2.6\%]), Trichosporon inkin $(1 / 39 ; 2.6 \%)$, and $T$. ovoid $(1 / 39[2.6 \%])$. The species identified in the control group were C. albicans $(3 / 6$ [50\%]), C. tropicalis $(1 / 6[16.7 \%])$, C. krusei $(1 / 6$ [16.7\%]), and Candida kefyr (1/6 [16.7\%]) (Table 5).

The distribution of oral complications according to the post-radiotherapy period showed that hyposalivation, xerostomia and oral candidiasis were more common in patients ranging from 19 to 36 months after the completion of radiotherapy.

\section{DISCUSSION}

In this study, the sample consisted of $43 / 55$ (78.2\%) men in each group, and 20/55 (36.4\%) of the patients 
Table 5. Presence of yeasts in patients who underwent radiotherapy at the Hospital of UOPECCAN $(n=55)$

\begin{tabular}{l|c|c|c}
\hline \multirow{2}{*}{$\begin{array}{c}\text { Number of } \\
\text { colonies }\end{array}$} & Study group & Control group & \multirow{2}{*}{ P-value } \\
\cline { 2 - 3 } & $\mathbf{N ~ ( \% )}$ & $\mathbf{N ~ ( \% )}$ & \\
\hline $1-399 \mathrm{UFC} / \mathrm{ml}$ & $6(10.9)$ & $2(3.6)$ & \\
\hline$>400 \mathrm{UFC} / \mathrm{ml}$ & $33(60)$ & $4(7.3)$ & \multirow{2}{*}{$0.0001^{\mathrm{b}}$} \\
\cline { 1 - 3 } Total & $39^{\mathrm{a}}(70.9)$ & $6^{\mathrm{a}}(10.9)$ & \\
\hline
\end{tabular}

\begin{tabular}{|c|c|c|c|}
\hline \multicolumn{4}{|l|}{ Yeast species } \\
\hline C. albicans & $25(64.1)$ & $3(50)$ & \multirow{9}{*}{$0.591^{\mathrm{c}}$} \\
\hline C. tropicalis & $5(12.8)$ & $1(16.7)$ & \\
\hline C. guilliermondii & $4(10.3)$ & 0 & \\
\hline C. krusei & $2(5.1)$ & $1(16.7)$ & \\
\hline C. glabrata & $1(2.6)$ & 0 & \\
\hline Trichosporon inkin & $1(2.6)$ & 0 & \\
\hline T. ovoid & $1(2.6)$ & 0 & \\
\hline C. Kefyr & 0 & $1(16.7)$ & \\
\hline Total & 39 & 6 & \\
\hline
\end{tabular}

${ }^{a}$ From the 55 patients of the study and control group, each one, in 39 and 6 patients it was possible to quantify the number of colonies and yeasts species, respectively.

${ }^{b}$ Statistically significant at the level $\mathrm{P}<0.05$ for number of colonies (Pearson's Chi-Square test).

${ }^{c}$ Not statistically significant at the level $\mathrm{P}>0.05$ for yeast species (Pearson's Chi-Square test).

were in the sixth decade of life (50 - 59 years), in each group as well. Of note, $51(92.7 \%)$ of the study group were smokers, including ex-smokers $44(80 \%)$ and current smokers $7(12.7 \%)$. According to some authors gender, age and the use of tobacco have been described as risk factors for the occurrence of head and neck cancer $[2,23,24]$ (Table 1).

The present study demonstrates that the majority of patients were diagnosed with squamous cell carcinoma $47(85.5 \%)$ and their diagnoses were performed in advanced stages considering that 37 $(67.3 \%)$ of those patients were classified in T3, T4 and T4a stages. About $44(80 \%)$ of the diagnoses were performed in III, IV and IVa clinical stages (Table 2). According to the study reported by Deboni et al. [25], $82.9 \%$ of the cases were squamous cell carcinoma, and $90.3 \%$ of the patients were diagnosed in stages III and IV (Table 2). These prevalences might be explained through the evaluation conducted by the National Oncology Care Policy enforced in Brazil, which demonstrated inadequacies in the early detection of cancer cases in the primary care network and the referral of these cases to specialized care, contributing to the late diagnosis of tumours [2].

Xerostomia was diagnosed in $45(81.8 \%)$ of patients undergoing radiotherapy in the head and neck regions using the conventional two-dimensional technique, and this percentage was similar to that $(80 \%)$ found by Deboni et al. [25], where in the patients were treated using megavoltage and telecobalt equipment. The radiotherapy techniques used for the treatment directly affects the occurrence of oral complications, as demonstrated by Lee and Ho [26], where in changes in the treatment technique in a hospital significantly decreased the rate of oral complications. Of note, the use of xerostomic medication such as antihypertensive and antidepressant reported by patients from the study and control groups was equivalent (19 [34.5\%] and 23 [41.9\%]), respectively (Table 1). However, the symptom of xerostomia was statistically higher in the study group because of the radiotherapy effects on the salivary glands (Table 3 ).

In our study, the prevalence of hyposalivation was $44(80 \%)$ in patients treated by conventional twodimensional radiotherapy and receiving doses higher than 50.5 Gy. This rate was similar to that found by Kam et al. [27], i.e., $82.1 \%$, where by patients received conventional two-dimensional radiotherapy. However, it was lower than that reported in the study by Guobis et al. [12], where hyposalivation reached $14 / 14(100 \%)$ of patients irradiated in the maxillofacial region with doses higher than 40 Gy. This difference in the rate of hyposalivation might be related to the radiotherapy technique used in the treatment, which was not described in the study by Guobis et al. [12], and the radiation field. These factors directly affect the prevalence of hyposalivation along with the dose. Therefore, studies have shown that higher doses are more harmful and that the parotid gland is more sensitive than the submandibular and sublingual glands to radiotherapy, which may be severely damaged with doses from 26 Gy $[\underline{5}, 27-31]$. Saliva plays an important role in essential functions, such as eating, swallowing, and speaking, and understanding its role in the mouth and the anatomy of the salivary glands is essential to control the adverse effects of radiotherapy, which affect the mouth and causes hyposalivation [32]

Candidiasis is the most common opportunistic infection in the mouth and is commonly present in irradiated patients. In this study, $15(27.3 \%)$ of patients in the study group had clinical signs of oral candidiasis, whereas $10(18.2 \%)$ of patients in the control group were diagnosed with candidiasis. In addition, in the control group, only the erythematous form was observed and all cases had removable dentures, who were mainly men. A different rate was reported in the study by Oliveira et al. [20], where 24/36 (66.7\%) of denture users presented candidiasis lesions and were mostly women, which could justify the observed difference. Candidiasis in our sample presented with the characteristics 
described in the literature, that is, an opportunistic infection affecting the mouth and occurring as a result of local or systemic factors. In the present study, 10 (18.2\%) patients from the control group used upper dentures and presented with chronic erythematous candidiasis which might be associated with the use of dentures (Table 4) [33-35]. Oppositely, in the study group besides chronic erythematous candidiasis (8 [53.3\%]), other types of oral candidiasis such as pseudomembranous candidiasis (3 [20\%]), angular cheilitis (2 [13.3\%]) and the association of both (2 [13.3\%]) identified in the study group are more associated with radiotherapy-related factors (Table 4) [15,36-39].

In the literature, several studies indicated changes in colonization by Candida sp. and the occurrence of yeast infections during and after radiotherapy in the head and neck regions [40-44]. In our sample, the presence of yeast colonization was observed in $39(70.9 \%)$ of patients undergoing radiotherapy for more than 6 months. Similarly, Azizi and Rezaei [43] found that the rate of colonization was $18 / 20(80 \%)$ after 2 weeks and 20/20 (100\%) 1 month after the completion of radiotherapy, and Guobis et al. [12] reported that the rate of colonization was $14(100 \%)$ 2 months after the of completion of radiotherapy. However, these rates differ from those of the study by Deng et al. [44] and Rossie et al. [40], corresponding to $39.1 \%$ and $47 \%$ of colonized patients after 1 month of radiotherapy, respectively. However, the reason for this difference is unknown. In our study, the postradiotherapy period was not significantly correlated with the presence of yeast infections; however, the majority (39.4\%) of colonized patients was in between 19 to 36 months post radiotherapy treatment.

C. albicans was found in 21/39 (87.5\%) of patients in the study group, which is similar to the results obtained in other studies involving irradiated patients $[\underline{37}, \underline{43}]$. This species was also common in patients undergoing immunosuppressive therapy [38], those with hyposalivation due to other causes $[\underline{45}, \underline{46}]$, and those with candidiasis [20]. However, the increased number of non-albicans Candida species in patients receiving radiotherapy in the head and neck regions has been discussed in the literature [42-44,47]. In this study, the prevalence of $C$. tropicalis, $C$. guilliermondii, and C. krusei was 5/39 (12.8\%), 4/39 $(10.3 \%)$ and $2 / 39(5.1 \%)$ respectively. In contrast, previous studies indicated that the prevalence of $\mathrm{C}$. tropicalis and C. krusei was $3 / 20(15 \%)$ and $4 / 20$ (20\%), respectively [43], and the prevalence of $C$. glabrata and C. kefyr was 3/39 (8\%) and 2/39 (5\%), respectively [37]. The yeast species and prevalence may be affected by conditions other than radiotherapy and need to be clarified. Lastly, the present study has some limitations. The frequency of radiation caries could not be evaluated appropriately given that $19(34.5 \%)$ patients of the study group used two complete removable dentures which could bias the results. Osteoradionecrosis was identified in only 2 patients from the study group so that larger samples and longer post radiotherapy period would be recommended to asses this late oral complication more consistently.

\section{CONCLUSIONS}

In the present study, xerostomia and hyposalivation were the more prevalent late oral complications related to radiotherapy when compared with oral candidiasis. The dental evaluation of patients irradiated in the head and neck regions should be performed systematically and periodically to minimize the damage that can be potentially caused by radiotherapy.

\section{ACKNOWLEDGEMENTS AND DISCLOSURE STATEMENTS}

The authors report no conflicts of interest related to this study.

\section{REFERENCES}

1. World Health Organization. Cancer Today: Data visualization tools for exploring the global cancer burden in 2018. International Agency for Research on Cancer. 2018. [URL: https://gco.iarc.fr/today/home]

2. Santos M de O. [Estimativa 2018: Incidência de Câncer no Brasil]. Rev Brasileira De Cancerologia. 2018 Mar 30;64(1):119-12. [doi: 10.32635/2176-9745.RBC.2018v64n1.115]

3. Vissink A, Jansma J, Spijkervet FK, Burlage FR, Coppes RP. Oral sequelae of head and neck radiotherapy. Crit Rev Oral Biol Med. 2003;14(3):199-212. [Medline: 12799323] [doi: 10.1177/154411130301400305]

4. Kolokythas A. Long-term surgical complications in the oral cancer patient: a comprehensive review. Part I. J Oral Maxillofac Res. 2010 Oct 1;1(3):e1. [Medline: 24421971] [PMC free article: 3886056] [doi: 10.5037/jomr.2010.1301] 
5. De la Cal C, Fernández-Solari J, Mohn C, Prestifilippo J, Pugnaloni A, Medina V, Elverdin J. Radiation produces irreversible chronic dysfunction in the submandibular glands of the rat. Open Dent J. 2012;6:8-13. [Medline: 22291861] [PMC free article: 3267234] [doi: 10.2174/1874210601206010008]

6. Gritz ER, Carmack CL, de Moor C, Coscarelli A, Schacherer CW, Meyers EG, Abemayor E. First year after head and neck cancer: quality of life. J Clin Oncol. 1999 Jan;17(1):352-60. [Medline: 10458254] [doi: 10.1200/JCO.1999.17.1.352]

7. Epstein JB, Robertson M, Emerton S, Phillips N, Stevenson-Moore P. Quality of life and oral function in patients treated with radiation therapy for head and neck cancer. Head Neck. 2001 May;23(5):389-98. [Medline: 11295813] [doi: $10.1002 /$ hed.1049]

8. PDQ Supportive and Palliative Care Editorial Board. Oral Complications of Chemotherapy and Head/Neck Radiation (PDQ $\left.{ }^{\circledR}\right)$ : Health Professional Version. 2016 Dec 16. In: PDQ Cancer Information Summaries [Internet]. Bethesda (MD): National Cancer Institute (US); 2002-. [Medline: 26389320]

9. Berti-Couto Sde A, Couto-Souza PH, Jacobs R, Nackaerts O, Rubira-Bullen IR, Westphalen FH, Moysés SJ, Ignácio SA, Costa MB, Tolazzi AL. Clinical diagnosis of hyposalivation in hospitalized patients. J Appl Oral Sci. 2012 Mar-Apr; 20(2):157-61. [Medline: 22666830] [PMC free article: 3894756] [doi: 10.1590/S1678-77572012000200006]

10. Chao KS, Majhail N, Huang CJ, Simpson JR, Perez CA, Haughey B, Spector G. Intensity-modulated radiation therapy reduces late salivary toxicity without compromising tumor control in patients with oropharyngeal carcinoma: a comparison with conventional techniques. Radiother Oncol. 2001 Dec;61(3):275-80. [Medline: 11730997] [doi: $10.1016 / \mathrm{S} 0167-8140(01) 00449-2]$

11. Navazesh M, Kumar SK; University of Southern California School of Dentistry. Measuring salivary flow: challenges and opportunities. J Am Dent Assoc. 2008 May;139 Suppl:35S-40S. [Medline: 18460678] [doi: 10.14219/jada.archive.2008.0353]

12. Guobis Ž, Kareivienė V, Basevičienė N, Paipalienė P, Niedzelskienė I, Sabalys G, Kubilius R, Gervickas A. Microflora of the Oral Cavity in Patients with Xerostomia. Medicina. 2011;47(11):94. [doi: 10.3390/medicina47120094]

13. Kakoei S, Haghdoost AA, Rad M, Mohammadalizadeh S, Pourdamghan N, Nakhaei M, Bahador M. Xerostomia after radiotherapy and its effect on quality of life in head and neck cancer patients. Arch Iran Med. 2012 Apr;15(4):214-8. [Medline: 22424038]

14. Sreebny LM, Valdini A, Yu A. Xerostomia. Part II: Relationship to nonoral symptoms, drugs, and diseases. Oral Surg Oral Med Oral Pathol. 1989 Oct;68(4):419-27. [Medline: 2571961] [doi: 10.1016/0030-4220(89)90140-0]

15. Lewis MA, Samaranyake LP, Lamey PJ. Diagnosis and treatment of oral candidosis. J Oral Maxillofac Surg. 1991 Sep;49(9):996-1002. [Medline: 1653314] [doi: 10.1016/0278-2391(91)90066-U]

16. Reichart PA, Samaranayake LP, Philipsen HP. Pathology and clinical correlates in oral candidiasis and its variants: a review. Oral Dis. 2000 Mar;6(2):85-91. [Medline: 10702784] [doi: 10.1111/j.1601-0825.2000.tb00106.x]

17. Neville BW, Damm DD, Allen CM, Chi AC. Fungal and Protozoal Diseases. In: Oral and Maxillofacial Pathology. 4th ed. London, UK: Elsevier; 2016. p. 213-21.

18. Epstein JB, Pearsall NN, Truelove EL. Quantitative relationships between Candida albicans in saliva and the clinical status of human subjects. J Clin Microbiol. 1980 Sep;12(3):475-6. [Medline: 7012183] [PMC free article: 273612] [doi: 10.1128/JCM.12.3.475-476.1980]

19. Navazesh M, Wood GJ, Brightman VJ. Relationship between salivary flow rates and Candida albicans counts. Oral Surg Oral Med Oral Pathol Oral Radiol Endod. 1995 Sep;80(3):284-8. [Medline: 7489270] [doi: 10.1016/S1079-2104(05)80384-1]

20. Oliveira MA, Carvalho LP, Gomes Mde S, Bacellar O, Barros TF, Carvalho EM. Microbiological and immunological features of oral candidiasis. Microbiol Immunol. 2007;51(8):713-9. [Medline: 17704633] [doi: 10.1111/j.1348-0421.2007.tb03960.x ]

21. Watters AL, Epstein JB, Agulnik M. Oral complications of targeted cancer therapies: a narrative literature review. Oral Oncol. 2011 Jun;47(6):441-8. [Medline: 21514211] [doi: 10.1016/j.oraloncology.2011.03.028]

22. Cooper CR Jr. Part II. Chapter 2. Yeasts Pathogenic to Humans. In: Kurtzman CP, Fell JW, Boekhout T. The yeasts: a taxonomic study. 5th ed. Burlington, MA: Elsevier Science; 2011. p. 9-21.

23. Siegel RL, Miller KD, Jemal A. Cancer Statistics, 2017. CA Cancer J Clin. 2017 Jan;67(1):7-30. [Medline: 28055103] [doi: 10.3322/caac.21387]

24. Ng SP, Pollard C 3rd, Kamal M, Ayoub Z, Garden AS, Bahig H, Gunn GB, Frank SJ, Skinner HD, Phan J, Berends J, Morrison WH, Johnson JM, Ferrarotto R, Sturgis EM, Mohamed ASR, Lai SY, Fuller CD, Rosenthal DI. Risk of second primary malignancies in head and neck cancer patients treated with definitive radiotherapy. NPJ Precis Oncol. 2019 Sep 27;3:22. [Medline: 31583278] [PMC free article: 6764977] [doi: 10.1038/s41698-019-0097-y]

25. Deboni AL, Giordani AJ, Lopes NN, Dias RS, Segreto RA, Jensen SB, Segreto HR. Long-term oral effects in patients treated with radiochemotherapy for head and neck cancer. Support Care Cancer. 2012 Nov;20(11):2903-11. [Medline: 22410861] [doi: 10.1007/s00520-012-1418-7]

26. Lee CC, Ho CY. Post-treatment late complications of nasopharyngeal carcinoma. Eur Arch Otorhinolaryngol. 2012 Nov;269(11):2401-9. [Medline: 22249834] [doi: 10.1007/s00405-011-1922-2] 
27. Kam MK, Leung SF, Zee B, Chau RM, Suen JJ, Mo F, Lai M, Ho R, Cheung KY, Yu BK, Chiu SK, Choi PH, Teo PM, Kwan WH, Chan AT. Prospective randomized study of intensity-modulated radiotherapy on salivary gland function in early-stage nasopharyngeal carcinoma patients. J Clin Oncol. 2007 Nov 1;25(31):4873-9. [Medline: 17971582] [doi: 10.1200/JCO.2007.11.5501]

28. Valdez IH, Atkinson JC, Ship JA, Fox PC. Major salivary gland function in patients with radiation-induced xerostomia: flow rates and sialochemistry. Int J Radiat Oncol Biol Phys. 1993 Jan;25(1):41-7. [Medline: 8416881] [doi: 10.1016/0360-3016(93)90143-J]

29. Valdés Olmos RA, Keus RB, Takes RP, van Tinteren H, Baris G, Hilgers FJ, Hoefnagel CA, Balm AJ. Scintigraphic assessment of salivary function and excretion response in radiation-induced injury of the major salivary glands. Cancer. 1994 Jun 15;73(12):2886-93. [Medline: 8199984] [doi: 10.1002/1097-0142(19940615)73:123.0.CO;2-K]

30. Eisbruch A, Ten Haken RK, Kim HM, Marsh LH, Ship JA. Dose, volume, and function relationships in parotid salivary glands following conformal and intensity-modulated irradiation of head and neck cancer. Int J Radiat Oncol Biol Phys. 1999 Oct 1;45(3):577-87. [Medline: 10524409] [doi: 10.1016/S0360-3016(99)00247-3]

31. Duarte VM, Liu YF, Rafizadeh S, Tajima T, Nabili V, Wang MB. Comparison of dental health of patients with head and neck cancer receiving IMRT vs conventional radiation. Otolaryngol Head Neck Surg. 2014 Jan;150(1):81-6. [Medline: 24145147] [doi: 10.1177/0194599813509586]

32. Humphrey SP, Williamson RT. A review of saliva: normal composition, flow, and function. J Prosthet Dent. 2001 Feb;85(2):162-9. [Medline: 11208206] [doi: 10.1067/mpr.2001.113778]

33. Morimoto K, Kihara A, Suetsugu T. Clinico-pathological study on denture stomatitis. J Oral Rehabil. 1987 Nov;14(6): 513-22. [Medline: 3481390] [doi: 10.1111/j.1365-2842.1987.tb00747.x]

34. Farah CS, Ashman RB, Challacombe SJ. Oral candidosis. Clin Dermatol. 2000 Sep-Oct;18(5):553-62. [Medline: 11134850] [doi: 10.1016/S0738-081X(00)00145-0]

35. Tarçın BG. Oral Candidosis: Aetiology, Clinical Manifestations, Diagnosis and Management. MÜSBED - J Marmara Univ Inst Health Sci. 2011 Aug;1(2):140-8. [URL: http:/www.exodontia.info/files/J_Marmara_Uni_Inst_Health_Sci_2011. Oral_Candidosis._Aetiology_Clinical_Manifestations_Diagnosis_Management.pdf]

36. Lynch DP. Oral candidiasis. History, classification, and clinical presentation. Oral Surg Oral Med Oral Pathol. 1994 Aug;78(2):189-93. [Medline: 7936588] [doi: 10.1016/0030-4220(94)90146-5]

37. Belazi M, Velegraki A, Koussidou-Eremondi T, Andreadis D, Hini S, Arsenis G, Eliopoulou C, Destouni E, Antoniades D. Oral Candida isolates in patients undergoing radiotherapy for head and neck cancer: prevalence, azole susceptibility profiles and response to antifungal treatment. Oral Microbiol Immunol. 2004 Dec;19(6):347-51. [Medline: 15491459] [doi: $10.1111 / \mathrm{j} .1399-302 x .2004 .00165 . x$ ]

38. Golecka M, Ołdakowska-Jedynak U, Mierzwińska-Nastalska E, Adamczyk-Sosińska E. Candida-associated denture stomatitis in patients after immunosuppression therapy. Transplant Proc. 2006 Jan-Feb;38(1):155-6. [Medline: 16504690] [doi: 10.1016/j.transproceed.2005.12.078]

39. Coronado-Castellote L, Jiménez-Soriano Y. Clinical and microbiological diagnosis of oral candidiasis. J Clin Exp Dent. 2013 Dec 1;5(5):e279-86. [Medline: 24455095] [PMC free article: 3892259] [doi: 10.4317/jced.51242]

40. Rossie KM, Taylor J, Beck FM, Hodgson SE, Blozis GG. Influence of radiation therapy on oral Candida albicans colonization: a quantitative assessment. Oral Surg Oral Med Oral Pathol. 1987 Dec;64(6):698-701. [Medline: 3320843] [doi: 10.1016/0030-4220(87)90171-X]

41. Ramirez-Amador V, Silverman S Jr, Mayer P, Tyler M, Quivey J. Candidal colonization and oral candidiasis in patients undergoing oral and pharyngeal radiation therapy. Oral Surg Oral Med Oral Pathol Oral Radiol Endod. 1997 Aug;84(2):149-53. [Medline: 9269016] [doi: 10.1016/S1079-2104(97)90061-5]

42. Redding SW, Zellars RC, Kirkpatrick WR, McAtee RK, Caceres MA, Fothergill AW, Lopez-Ribot JL, Bailey CW, Rinaldi MG, Patterson TF. Epidemiology of oropharyngeal Candida colonization and infection in patients receiving radiation for head and neck cancer. J Clin Microbiol. 1999 Dec;37(12):3896-900. [Medline: 10565903] [PMC free article: 85839] [doi: 10.1128/JCM.37.12.3896-3900.1999]

43. Azizi A, Rezaei M. Prevalence of Candida species in the oral cavity of patients undergoing head and neck radiotherapy. J Dent Res Dent Clin Dent Prospects. 2009 Summer;3(3):78-81. [Medline: 23230489] [PMC free article: 3517277$]$ [doi: 10.5681/joddd.2009.020]

44. Deng Z, Kiyuna A, Hasegawa M, Nakasone I, Hosokawa A, Suzuki M. Oral candidiasis in patients receiving radiation therapy for head and neck cancer. Otolaryngol Head Neck Surg. 2010 Aug;143(2):242-7. [Medline: 20647128] [doi: 10.1016/j.otohns.2010.02.003]

45. Abraham CM, al-Hashimi I, Haghighat N. Evaluation of the levels of oral Candida in patients with Sjögren's syndrome. Oral Surg Oral Med Oral Pathol Oral Radiol Endod. 1998 Jul;86(1):65-8. doi: 10.1016/s1079-2104(98)90151-2. [Medline: 9690247] [doi: 10.1016/S1079-2104(98)90151-2]

46. Shinozaki S, Moriyama M, Hayashida JN, Tanaka A, Maehara T, Ieda S, Nakamura S. Close association between oral Candida species and oral mucosal disorders in patients with xerostomia. Oral Dis. 2012 Oct;18(7):667-72. [Medline: 22548381] [doi: 10.1111/j.1601-0825.2012.01923.x] 
47. Karbach J, Walter C, Al-Nawas B. Evaluation of saliva flow rates, Candida colonization and susceptibility of Candida strains after head and neck radiation. Clin Oral Investig. 2012 Aug;16(4):1305-12. [Medline: 21904917] [doi: 10.1007/s00784-011-0612-1]

\section{To cite this article:}

Martinez AC, Silva IMV, Berti Couto SA, Gandra RF, Rosa EAR, Johann ACBR, Couto Souza PH.

Late Oral Complications Caused by Head and Neck Radiotherapy: Clinical and Laboratory Study

J Oral Maxillofac Res 2020;11(3):e3

URL: http://www.ejomr.org/JOMR/archives/2020/3/e3/v11n3e3.pdf

doi: $\underline{10.5037 / \text { jomr.2020.11303 }}$

Copyright (C) Martinez AC, Silva IMV, Berti Couto SA, Gandra RF, Rosa EAR, Johann ACBR, Couto Souza PH. Published in the JOURNAL OF ORAL \& MAXILLOFACIAL RESEARCH (http://www.ejomr.org), 30 September 2020.

This is an open-access article, first published in the JOURNAL OF ORAL \& MAXILLOFACIAL RESEARCH, distributed under the terms of the Creative Commons Attribution-Noncommercial-No Derivative Works 3.0 Unported License, which permits unrestricted non-commercial use, distribution, and reproduction in any medium, provided the original work and is properly cited. The copyright, license information and link to the original publication on (http://www.ejomr.org) must be included. 